\title{
Establishing the Thematic Structure and Investigating the most Prominent Theta Roles Used in Sindhi Language
}

\author{
Zahid Ali Veesar (Corresponding author) \\ Faculty of Linguistics, University of Malaya, Malaysia \\ E-mail: zahiimahii85@gmail.com \\ Kais Amir Kadhim \\ Faculty of Linguistics, University of Malaya, Malaysia \\ E-mail: kaisamir@um.edu.my \\ Sridevi Sriniwass \\ Faculty of Linguistics, University of Malaya, Malaysia \\ E-mail: sridevi@um.edu.my
}

Received: 07-12- 2014

Published: 01-07- 2015
Accepted: 21-02- 2015

doi:10.7575/aiac.ijalel.v.4n.4p.216
Advance Access Published: February 2015

URL: http://dx.doi.org/10.7575/aiac.ijalel.v.4n.4p.216

\begin{abstract}
This study focuses on the thematic structure of the Sindhi verbs to find theta roles in the Sindhi language. The study tries to answer the research questions; "What are the thematic structures of Sindhi verbs?" and "What are the prominent theta roles in the Sindhi language?" It examines the argument/thematic structure of Sindhi verbs and also finds the theta roles assigned by the Sindhi verbs to their arguments along with the most prominent theta roles used in the Sindhi language. The data come from the two interviews taken from two young native Sindhi speakers, which consist of 2 hours conversation having 1,669 sentences in natural spoken version of the Sindhi language. Towards the end, it has been found that the Sindhi language has certain theta roles which are assigned by the verbs to their arguments in sentences. Each verb phrase in our data is thus examined and studied in detail in terms of Argument/Thematic structure in order to find theta roles in Sindhi language. Thus, in this regard, each verb phrase (in a sentence) has been examined with the help of Carnie's theoretical framework (Thematic Relation and Theta Roles: 2006) in order to find the prominent theta roles in the Sindhi language. The data have been examined and analysed on the basis of the Carnie's theoretical framework. The study finds that the Sindhi language has all (09) theta roles which have been proposed by Carnie (2006). It has been found that six prominent theta roles out of nine are used prominently in Sindhi. The six prominent theta roles in Sindhi language are: agent, theme, beneficiary, recipient, locative and goal.
\end{abstract}

Keywords: Sindhi Language, Syntax, Semantics, Theta role/thematic relations, prominent theta roles

\section{Introduction}

Theta-role ( $\theta$-role) is a bundle of thematic relations associated with a particular argument (Carnie, 2006). The verb phrase in the following example has three arguments and five thematic relations associated with them.

- $\quad$ Ali gave a gift to Peter.

(Ali is an agent who is doing an action of giving a gift to Peter. It is also a source in the sentence; the context of the sentence shows that "a gift" goes from Ali to Peter. Thus, keeping this reason in mind, Ali is also a source in the above sentence. Theme of the sentence is "a gift" which undergoes an action of the sentence; it is being given to Peter. "Peter" is a person who receives a gift from Ali. Peter is therefore recipient of the gift in the sentence. Peter is also goal in the sentence; a gift comes from Ali to Peter. Peter is the termination or destination of the gift to reach. Thus, in this way the three arguments (Ali, a gift and Peter) have five theta roles in the above sentence).

Carnie (2006) defines Theta- Criterion as that Lexical information. According to his Theta-Criterion Theory each argument is assigned one and only one theta-role and each theta-role is assigned to one and only one argument.

Carnie says theta role is a semantic relation between the argument and the predicate (verb phrase). Through verb we can come to know what relations they have, and also how arguments are related to the predicate in the sentence.

Radford (2009) defines that the theta-roles are used to describe the semantic roles played by arguments in the sentences. We can illustrate this definition in the following examples:

[The police] arrested [him]

(Agent) (Theme) 
In this example the argument "the police" has the role of an agent who is doing an action of arresting "him". The second argument "him" has the role of theme which undergoes an action of being arrested by the police. In this way the arguments have an agent and a theme theta relation with each other in the sentence.

Theta roles are the names of the participant roles associated with a predicate: the predicate may be a verb, an adjective, a preposition, or a noun. The participant is usually said to be an argument of the predicate.

\subsection{Statement of the Problem}

There is no proper work on Syntax of the Sindhi language (Fahmida, 2011; Sazia, 2009). On one hand, Sindhi language is known as the oldest and one of major languages of India and Pakistan in general and Sindh province in particular. We can find number of books on general grammar, phonology and morphology of Sindhi language. However, its major part which is syntax (structure) has been ignored or left behind all this while. We can find lot of work on Sindhi grammar in general but less or no work on syntax in particular. Writers like Stack (1849), Trump (1872), Munshi (1892) and Qaleech (1916) have generally talked about morphology, phonology, grammar and parts of speech of the Sindhi language. None of them and their followers has discussed about syntax of Sindhi language; either it had been ignored or these are the modern terms in language and at that time these were not well known to those writers/linguists. However; it is still being ignored by the present day writers (Memon, 1987; Shazia, 2009; Fahmida, 2010; Rahman, 2010; Jokhio, 2012). The aim of this study is to analyse verb phrase in Sindhi language in terms of Argument structure, Theta roles and the prominent theta roles used in the Sindhi language. Thus, this study attempts to analyse theta roles and the most prominent theta roles used in Sindhi language. It aims to see the structure of arguments (Noun phrases: subjects, objects and other nouns) in the Sindhi sentence, and also to see the thematic structure which shows thematic relations of theta roles.

\subsection{Related Literature about Sindhi Verbs}

Verb plays a crucial role in a sentence; they show an action of a sentence. Verbs show what the subject and object are doing in the sentence. Verbs are called body of sentence. Jokhio (2011) defines Sindhi verb that anything which tells or shows something, any action, state or condition of someone in the sentence that is called a verb. Jokhio (2012) divides the Sindhi verbs into two types; main verbs and to be or auxiliary verbs. Main verbs are further divided into regular and irregular verbs and auxiliary verbs, which are further divided into free auxiliaries and linking auxiliaries. However, Qaleech (2006) says the Sindhi verbs have been derived from imperative form. He says Sindhi imperatives are Sindhi nouns but they do the function of verb and hence many other verb forms are derived from the imperative that is why they are called base forms in the Sindhi language. He further says nominative, accusative and state cases of noun are also derived from the imperatives. Bheerumal (1985) defines irregular verbs are those whose objects do not come/link directly in the sentences. Arshad (1986) says that regular verbs are those verbs which are derived from infinitives by adding suffixes "yo= يو or yal= يو"

Sindhi verbs have been divided into intransitive verbs and transitive verbs, and these are further classified into sub parts (See Khoso, 2005; Rashidi, 2007; Chano, 2011; Dada, 2010; Jokhio 2012; Jokhio, 2013; Qaleech, 2006; Bheerumal, 1985 \& Allana, 2010.) Jokhio (2012) says that Sindhi verbs need to be studied and carried out at M.Phil. or PhD level so that it could be studied in detail.

\subsection{Related Studies on Argument Structure}

Luuk E. (2009) argues that that the predicate/argument structure of natural language is much more complex than that of first order predicate logic. He says language has fossils and according to Jackendoff (1999) language has five fossils; by language fossils he means to say language structural features. He finds that linguistic predicate/ argument structure has universal approach in natural language syntax. He says that linguistic arguments are universally marked by determiners, possessors and word order constraints, while linguistic predicates are universally marked by the tense, mood, aspect, voice and also word order constraints. Besides, Verhoeven E. (2014) studies thematic prominence and animacy asymmetries cross linguistically in four heterogeneous languages namely Greek, German, Chinese and Turkish. According to him and others (Jackendoff, 1987, Grimshaw, 1990; Dik, 1978; Lavin and Rappaport, 2005), agent theta roles are higher than others because of the animacy effects. Towards the end, he finds that the experiencer-first effects are observed in Greek and German but not in Turkish and Chinese. He concludes that animacy effects in arguments are not universally accepted; they differ from language to language.

On the other hand, Harley H. (2012) studies external arguments (subjects) and the Mirror Principle. He asks two research questions: 1) what are arguments? 2) How are they suppressed? According to Mirror Principle (Baker, 1985), morphological derivations are syntactic derivations; meaning that morphology leads to syntax. He says applied arguments come structurally between external and internal arguments. These arguments are beneficiaries and always come with ditransitive verbs; can be seen in the Hiaki language. The causative verbs introduce external arguments in Hiaki, and applicative morphemes introduce internal arguments. According to Rude (1996), applied arguments are structurally lower than external arguments, and structurally higher than internal arguments in a sentence. (See also, Holmerg A. \& Roberts I. 2012; Kratzer, 1996; Simpson A., Choudhury A.; Meno M. 3013 \& Marantz A., 2012).

\subsection{Related studies on Hierarchy of theta roles}

Bierwisch M. (2006) studies the thematic roles and their universal, particular and idiosyncratic aspects. He says arguments are placed hierarchically in different languages. Theta roles are assigned according to the structure of expressions and theta roles can also be content based. His hierarchy of the theta roles is: Agent $>$ Recipient $>$ 
Experiencer/Goal > Instrument > Patient/Theme > Place. William E. (1987), however, says that there are three species of theta role assignment namely internal theta role assignment, external theta role assignment and predication. External arguments are subjects, internal arguments are objects and predication is the action in the sentence. He introduces the concept of Implicit Arguments which are not assigned any theta roles in the sentence. (See also Willits J. A., D’Mello S. K., Duran N. D. \& Olney A., 2007)

Hovav M. R. (2004), on the other hand, studies the thematic hierarchies which he says is a ranking of a set of semantic roles. He says there are problems in the thematic hierarchies, because it is not universal; different writers give different hierarchies.

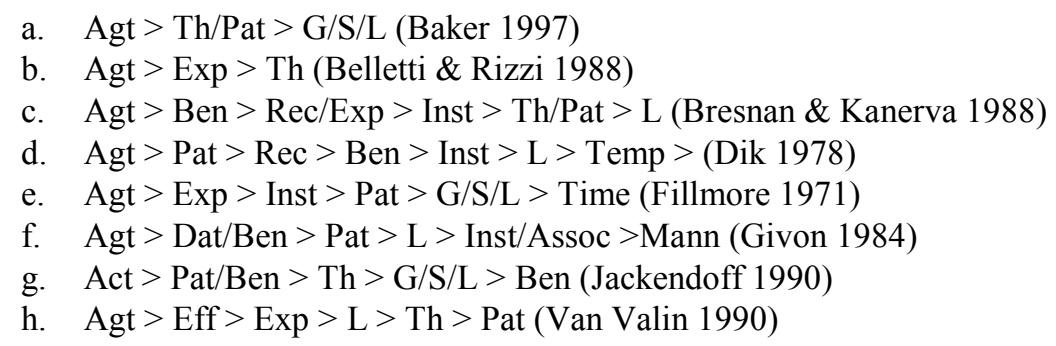

It can be seen that all of the above writers/linguists propose different hierarchy of the theta roles. The prominence of theta roles differs from language to language. According to Dowty (1991:572), semantic elements help realize the arguments and assign the theta roles to them accordingly. He rejects the Fillmore's well-known subject selection paradigm. He concludes that each thematic hierarchy is worthy as it contributes to the knowledge regarding theta roles and their hierarchy/prominence. Like Panini's sematic roles, Fillmore's (1968) 'deep cases' are basis for thematic roles in modern linguistics. Regarding the hierarchy of roles, Fillmore (1968:33) says 'If there is an A, it becomes the subject; otherwise if there is an 'I', it becomes the object; otherwise the subject is O. Jakendoff's (1972) hierarchy is different from that of Fillmore:

agent $>$ beneficiary $>$ recipient/experiencer $>$ instrument $>$ theme $>$ location

One argument can have more than one theta roles (Jackendoff, 1990:59). Agents are not arguments of verbs; they are external arguments (see Kratzer, 1996).

Thematic relations relate situation to their participants; they show relation between participants and situations, and they are interface between syntax and semantics (Davis A. R. 2009). They are also called the relational notions which label arguments and predicates; they show relation between participants/arguments and events (Chierchia, 1984). Thematic hierarchy means prominence of the theta roles which ultimately leads to the syntactic prominence. There is no fixed hierarchy of thematic roles (see Fillmore, 1977; Jackendoff, 1987; Levin \& Rappaport Hovav, 2005; Grimshaw, 1990; William, 1994; Dowty, 1991). Baker M. C. (1996) studies the thematic relations and the syntactic structure. He says there are external and internal arguments in an expression. English language takes Agents as subjects and Patients as objects; and subjects are higher than objects. English has some verbs which take only one argument, others take two arguments, and there are some verbs like 'give' which take three arguments. Baker gives the thematic hierarchy proposed by Larson (1988: 382):

Agent $>$ Theme $>$ Goal $>$ Obliques (manner, location, time, $\ldots$ )

However, Baker suggests creating a new thematic hierarchy which has universal approach to all languages. Baker says Theme theta role is higher than Goal theta role, and thus he rejects the Grimshaw's (1990) theory of thematic hierarchy where she places Theme lower than Goal. He concludes that thematic roles are semantic roles, while aspectual roles are completing events of the verbs.

\subsection{Thematic Relation and Theta Roles}

One way of encoding selectional restrictions is through the use of what are called thematic relations. These are particular semantic terms that are used to describe the role that the argument plays with respect to the argument. This section describes some common thematic relations (this list is by no means exhaustive, and the particular definitions are not universally accepted).

The initiator or doer of an action is called the agent. In the following sentences, Ryan and Michael are agents.

Agents are most frequently subjects, but they can also appear in other position.

Arguments that feel or perceive events are called experiencers.

Experiencers can appear in a number of argument positions including subject and object:

Entities that undergo actions, are moved, experienced or perceived are called themes.

The entity towards which motion takes place is called a goal. Goals may involve abstract motion:

There is a special kind of goal called recipient. Recipients only occur with verbs that denote a change of possession:

The opposite of a goal is the source. This is the entity from which a motion takes place:

The place where the action occurs is called the location: 
The object with which an action is performed is called the instrument:

Finally, the one for whose benefit an event took place is called the beneficiary:

Notice that any given DP can have more than one thematic relation. In the following sentence, the DP Jason bears the thematic relations of agent and source (at the very least).

- Jason gave the books to Anna.

There is not a one-to-one relationship between thematic relations and arguments. However, linguists have a special construct called a theta role (or $\theta$ role), that does map one-to-one with arguments. Theta roles are bundles of thematic relations that cluster on one argument. In (15) above, Jason gets two thematic relations (agent and source), but only one theta role (the one that contains the agent and source thematic relations).

\section{Methodology}

This research work is a qualitative research (Creswell, 2004); it tries to explore the verbs and types of verbs in the Sindhi language. It will be explored to see the place/position, importance, function and relation of verb with other elements in the sentence. It will be seen how Sindhi verbs are formed and used in sentences. It has been attempted to see how Sindhi verbs assign theta-roles to their arguments. The processes and relations of Sindhi verbs will be explored with the help of Andrew Carnie's theory of Theta-roles (2006:221).

\subsection{Research Design}

The research design used in this research work is exploratory and descriptive (Creswell, 2004) and it uses qualitative method (Creswell, 2004). The natural Sindhi language (spoken/oral form) has been selected to study nature and function of the Sindhi verbs. This research design helped us study verbs, its types and the theta-roles assigned by the verbs to their arguments in Sindhi language. The argument structure of the Sindhi verbs has been established with the help of the Carnie's theoretical framework and the research design.

\subsection{Data Collection}

The research methodology comprises two parts; data collection and data analysis (Creswell, 2004). The current study analyses verb phrases in Sindhi language in terms of their argument structure, theta roles and particularly the most prominent theta roles used in Sindhi. The data for the study comes from the native Sindhi speakers who have Sindhi as their first language or mother tongue. The data have been collected through two informal interviews. Interviews have been taken from the two native Sindhi speakers. The researcher asked them questions informally regarding their different things in order to make them confident enough to speak more freely and frankly about their lives in a natural way. The questions were regarding their personal lives, education (from primary to university life), their current position and status, their family, their present life, previous life and future goals and intentions. The participants were given free atmosphere to speak freely in a natural way as if they were talking to each other without being noticed and recorded. There were two interviews and each interview was taken separately. The interview one comprised of (864) sentences in the (56) minutes and (49) seconds time. The second interview consisted (815) sentences in (45) minutes and (09) seconds time.

\section{Data Analysis and Discussion}

The data have been analysed with the help of Carnie's theoretical framework (Carnie, 2006), which is also used as analytical framework in the current study. It has been tried to explore the Sindhi verbs and its types and also to see their function, position and importance in the sentences. It has been attempted to see how Sindhi verbs assign different thetaroles (also called theta relations) to their arguments (NPs) in sentences. The argument structure of the Sindhi verbs has been established to see the theta-roles and the most prominent theta roles with Sindhi verbs.

3.1 Theta Roles/Thematic Relations in Sindhi

\subsubsection{Agent}

The examples (01) to (02) establish the Argument Structure of the verb and analyse the Agent theta roles assigned by the verbs to their arguments.

Example 01. ته اسان ان كي وايس مينتين كرن جاهيون تثنا

\begin{tabular}{|c|c|c|}
\hline $\begin{array}{l}\text { S. NO/ } \\
\text { coding }\end{array}$ & $\begin{array}{l}\text { Sentence } \\
\text { Description }\end{array}$ & Sentence \\
\hline \multirow[t]{5}{*}{ M121 } & Sindhi in Arabic & تله اسان ان كي و إيس مينتين كرن جاهيون ثّا. \\
\hline & Sindhi in Roman & Ta assan una khy wapas maintain karan tha chahyon. \\
\hline & Transliteration & $\begin{array}{l}\text { Ta=that; assan=we; una=it; khy=have; wapas=back; } \\
\text { maintain; karan=to do; tha=agreement; chahyon=want. }\end{array}$ \\
\hline & Translation & We want to maintain it back. \\
\hline & $\begin{array}{l}\text { Syntactic } \\
\text { Analysis }\end{array}$ & 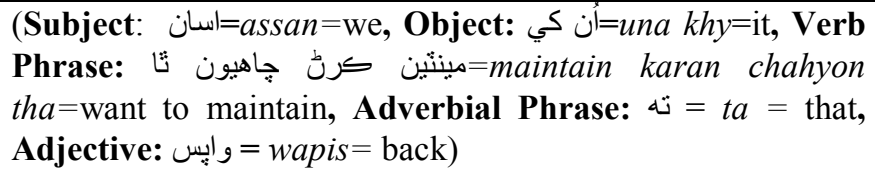 \\
\hline
\end{tabular}


جي أُء اسيسمينت كندو هوس .Example 02

\begin{tabular}{|c|c|c|}
\hline $\begin{array}{l}\text { S. NO/ } \\
\text { coding }\end{array}$ & $\begin{array}{l}\text { Sentence } \\
\text { Description }\end{array}$ & Sentence \\
\hline \multirow[t]{5}{*}{ M192 } & Sindhi in Arabic & جي آيُ اسيسمينت كندو هوس. \\
\hline & Sindhi in Roman & Ji aaon assessment kando hos. \\
\hline & Transliteration & $\mathrm{Ji}=\mathrm{yes} ;$ aaon=I; assessment; $\mathrm{kando}=\mathrm{do} ; \mathrm{hos}=$ was. \\
\hline & Translation & Yes, I used to do assessment. \\
\hline & $\begin{array}{l}\text { Syntactic } \\
\text { Analysis }\end{array}$ & 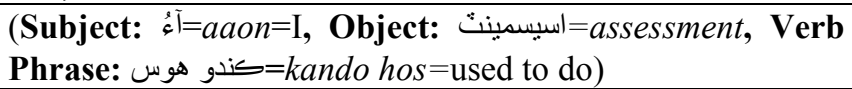 \\
\hline
\end{tabular}

The verb phrase in the above sentence is "مينتين كرن جاهيون ثنان=maintain karan chahyon tha=want to maintain". There

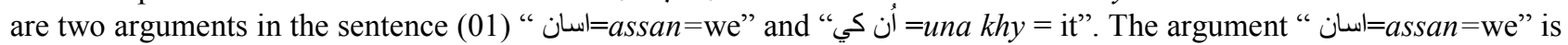
the subject of the sentence which is a first person plural pronoun and has a masculine gender. It is used at the place of a proper noun (persons or people) and it has capability to do action in the sentence. We can therefore say that it is subject or agentof the sentence which performs an action of maintaining something or doing something in the sentence, and it has an agentive thematic relation in the sentence. The other argument of the sentence "أن كي the sentence. This is the argument which undergoes the action (of maintaining) of the sentence. It does not do an action but undergoes an action of the sentence. Thus, we can say that it is the theme of the sentence and has the theme theta role in the sentence.

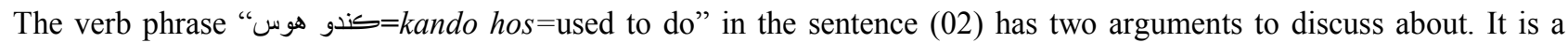
transitive verb which takes two arguments to pass action from one argument " "assessment" (object). This is the argument which performs an action of doing assessment in the sentence. We can therefore say that this argument is subject or agent of the sentence. On the other hand, the second argument of the sentence "اسيسمينتassessment" is the one which undergoes an action (of being done) of the sentence. The context shows that subject of the sentence "I" is doing an "assessment" of something in the sentence. We can therefore say that it is the object or the theme of the sentence with theme theta relation in the sentence $(02)$.

\subsubsection{Experiencer Theta Role}

Experiencer or perceiver of the event is called an experiencer (Carnie, 2006). It is the one who experiences something in the sentence.

Example 03. هكرّو توهان كي خواب آيو

\begin{tabular}{|c|c|c|}
\hline $\begin{array}{l}\text { S. NO/ } \\
\text { coding }\end{array}$ & $\begin{array}{l}\text { Sentence } \\
\text { Description }\end{array}$ & Sentence \\
\hline \multirow[t]{5}{*}{ M159 } & Sindhi in Arabic & هكرٌّو تو هان كي خو اب آيو. \\
\hline & Sindhi in Roman & Hikro tahan khy khuwab ayo. \\
\hline & Transliteration & $\begin{array}{l}\text { Hikro=one; } \quad \text { tahan=you; } \quad \text { khy=have; } \quad \text { khuwab=dream; } \\
\text { ayo=came. }\end{array}$ \\
\hline & Translation & You saw a dream. \\
\hline & $\begin{array}{l}\text { Syntactic } \\
\text { Analysis }\end{array}$ & 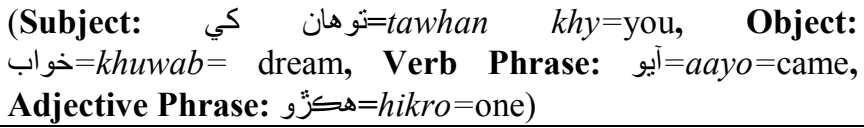 \\
\hline
\end{tabular}

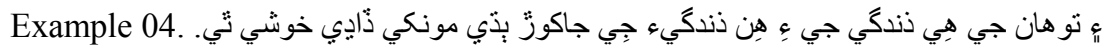

\begin{tabular}{|c|c|c|}
\hline $\begin{array}{l}\text { S. NO/ } \\
\text { coding }\end{array}$ & $\begin{array}{l}\text { Sentence } \\
\text { Description }\end{array}$ & Sentence \\
\hline \multirow[t]{5}{*}{ N546 } & Sindhi in Arabic & 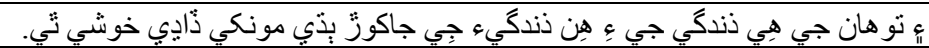 \\
\hline & Sindhi in Roman & $\begin{array}{l}\text { Ain tahan ji he zindgi ji ain hin zindgi ji jakhor budhi mokhy } \\
\text { dadhi khushi thee. }\end{array}$ \\
\hline & Transliteration & $\begin{array}{l}\text { Ain=and; } \operatorname{tahan}=\text { you; } \mathrm{ji}=\text { of; hee=this; } \text { zindgi }=\text { life; } \mathrm{ji}=\mathrm{of} \text {; ain=and; } \\
\text { hin=this; zindgi=life; ji=of; jakhor=struggle; budhi=heard; } \\
\text { mokhy=I; dadhi=very; khushi=happiness; thee=agreement. }\end{array}$ \\
\hline & Translation & $\begin{array}{l}\text { I felt very happy after hearing your life and your life's struggle. } \\
\text { Or } \\
\text { Having heard your life and your life's struggle I felt happiness. }\end{array}$ \\
\hline & $\begin{array}{l}\text { Syntactic } \\
\text { Analysis }\end{array}$ & 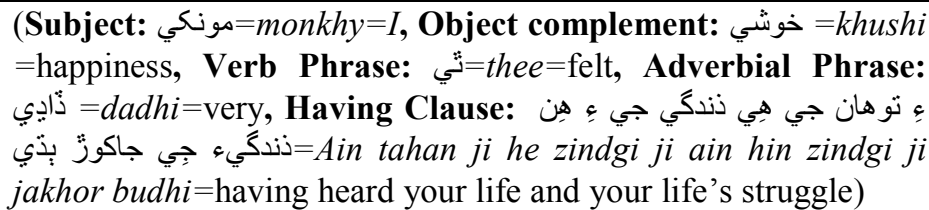 \\
\hline
\end{tabular}


The verb phrase "آيو=aayo=came" of the sentence (03) has two arguments. The arguments are "نو "خواب=khuwab=dream". The first argument is second person singular and it has capability to do an action in the sentence. The second person singular pronoun either does an action (agent) in the sentence or sometimes gets benefit (beneficiary) in the sentence. It is usually used either as a subject (Agent) which performs an action or as an indirect object which gets benefit in the sentence. None of the case is here; it neither does an action nor gets benefit in the sentence, but it experiences something which we cannot see (he sees a dream). In this case thus, it can be said that it is experiencer in the sentence (03), which experiences something, and it has the experiencer theta role in the sentence. The second argument "خواب=khuwab=dream" is the object or the theme of the sentence, and it has the theme theta role in the sentence.

We have two arguments (noun phrases) and a complement phrase with the verb " $ث=$ thee=felt" of the sentence (04). The arguments/noun phrases are: "مونكي=monkhy=I/me" and "خوشي" hhushi=happiness". The first noun phrase does not do an action in the sentence but it just feels or experiences an action (of feeling) in the sentence; it feels 'happiness' in the sentence. We can therefore say that the argument " مونكي=monkhy=I/me" is the experiencer of the sentence, and it has an experiencer theta relation in the sentence. The second argument "خوني" which cannot be seen or touched but just felt. It is object of the sentence and it has an accusative case, because it is used as an object of the sentence. Thus, it can be said that this argument is theme or object of the sentence.

\subsubsection{Theme Theta Role}

Carnie (2006) defines theme as the entity that undergoes actions, are moved, experienced or perceived by someone or something.

Example 05. مان توهان جي بولي ركارب كندس

\begin{tabular}{|c|c|c|}
\hline $\begin{array}{l}\text { S. NO/ } \\
\text { coding }\end{array}$ & $\begin{array}{l}\text { Sentence } \\
\text { Description }\end{array}$ & Sentence \\
\hline \multirow[t]{5}{*}{ N11 } & Sindhi in Arabic & مان تو هان جي بولي ركارب كندس. \\
\hline & Sindhi in Roman & Maan tahan ji boli record kandus. \\
\hline & Transliteration & $\begin{array}{l}\text { Maan=I; tahan=you; ji=of; boli=language; record; kandus=do } \\
\text { will. }\end{array}$ \\
\hline & Translation & I will record your language. \\
\hline & $\begin{array}{l}\text { Syntactic } \\
\text { Analysis }\end{array}$ & 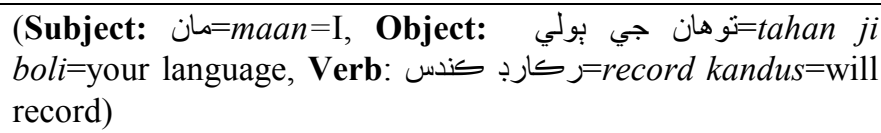 \\
\hline
\end{tabular}

تها آٌٌ أنهي شيء كي هِي فالو كندس .Example 06

\begin{tabular}{|c|c|c|}
\hline $\begin{array}{l}\text { S. NO/ } \\
\text { coding }\end{array}$ & $\begin{array}{l}\text { Sentence } \\
\text { Description }\end{array}$ & Sentence \\
\hline \multirow[t]{5}{*}{ M830 } & Sindhi in Arabic & تها آعُ أنهي شيء كي هِي فالو كندس \\
\hline & Sindhi in Roman & Ta aaon unhe shae khy he follow kandus. \\
\hline & Transliteration & $\begin{array}{l}\text { Ta=that; aaon=I; unhe=that; shae=thing; khy=have; } \\
\text { hee=also; follow; kandus=will do. }\end{array}$ \\
\hline & Translation & I will follow only that thing. \\
\hline & $\begin{array}{l}\text { Syntactic } \\
\text { Analysis }\end{array}$ & 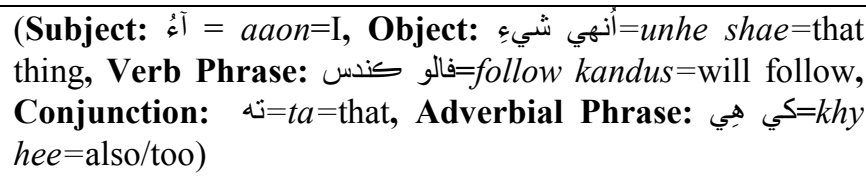 \\
\hline
\end{tabular}

The verb phrase " "ركارب كندس"record kandus=will record" of the sentence (05) has two arguments to discuss about. The first argument "مان=maan=I" is the subject or agent of the sentence which performs an action of recording somebody's language in future, and it has nominative case in the sentence. The other argument " تو هان جي بولي =tahan ji boli=your language" is an object of the sentence which undergoes an action of the sentence in the future. This is the argument that undergoes an action of the sentence (will be recorded by the subject) in the future. This is the argument that is focus or theme of the sentence and it has an accusative case in the sentence, because it is used as an object of the sentence. Therefore; we can say that this argument is the theme of the sentence and has theme theta role in the sentence.

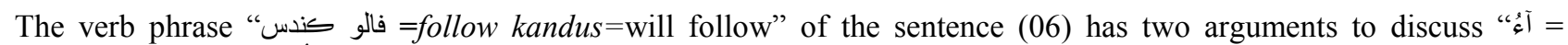

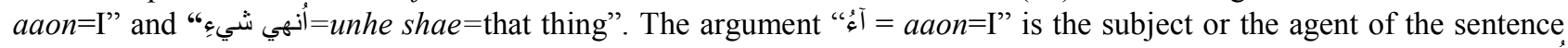
with nominative case, and it has an agent theta relation in the sentence. On the other hand, the other argument " شيs =unhe shae=that thing" is an NP used as an object of the sentence, as it has capability of undergoing an action of something/ somebody rather than doing any action. A thing cannot do any action on its own, but it can undergo an 
action of the sentence. The context of the sentence shows that it is the object or theme of the sentence and it has an accusative case. This is the argument which is focus or theme of the sentence, and it has theme thematic relation.

\subsubsection{Goal Theta Role/Relation}

Carnie (2006) defines goal as the entity towards which motion takes place in the sentence. Goals may also involve abstract motion.

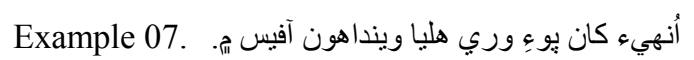

\begin{tabular}{|c|c|c|}
\hline $\begin{array}{l}\text { S. NO/ } \\
\text { coding }\end{array}$ & $\begin{array}{l}\text { Sentence } \\
\text { Description }\end{array}$ & Sentence \\
\hline \multirow[t]{5}{*}{ M55 } & Sindhi in Arabic & أُنهيء كان يو وِ وري هليا وينداهون آفيس ش. \\
\hline & Sindhi in Roman & Unhe khan poi wari halya wenda hon office mei. \\
\hline & Transliteration & $\begin{array}{l}\text { Unhe=that; khan=from; poi=then; wari }=\text { then; halya }=\text { go; } \\
\text { wenda=will go; hyon=are; aafice }=\text { office; mei }=\text { in. }\end{array}$ \\
\hline & Translation & $\begin{array}{l}\text { Then (we) go back to the office. Or } \\
\text { After that (we) get back in the office. }\end{array}$ \\
\hline & $\begin{array}{l}\text { Syntactic } \\
\text { Analysis }\end{array}$ & 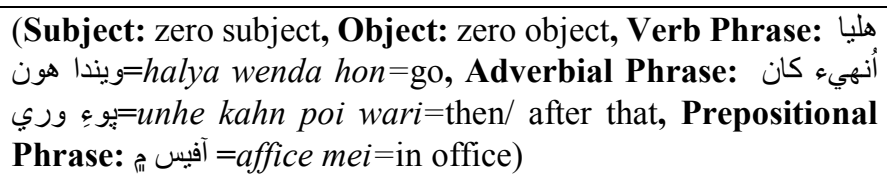 \\
\hline
\end{tabular}

Example 08. تها أتي اجي ويندا آهيون كهر ينهنجي

\begin{tabular}{|c|c|c|}
\hline $\begin{array}{l}\text { S. NO/ } \\
\text { coding }\end{array}$ & $\begin{array}{l}\text { Sentence } \\
\text { Description }\end{array}$ & Sentence \\
\hline \multirow[t]{5}{*}{ N107 } & Sindhi in Arabic & تـه أتتي اجي ويندا آهيون كهر يُنهجي. \\
\hline & Sindhi in Roman & Ta uty achi wenda aahyon ghar pahinje. \\
\hline & Transliteration & $\begin{array}{l}\text { Ta=that; uty=there; achi }=\text { come; wenda }=\text { will go; aahyon=are; } \\
\text { ghar=home; pahinje=our/own. }\end{array}$ \\
\hline & Translation & Then (we) come (back) there our home. \\
\hline & $\begin{array}{l}\text { Syntactic } \\
\text { Analysis }\end{array}$ & 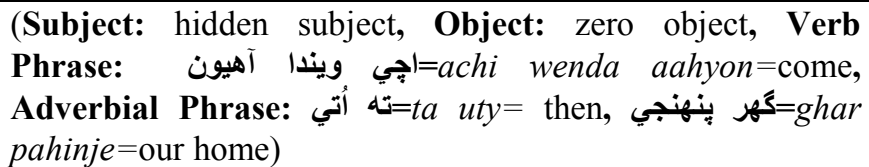 \\
\hline
\end{tabular}

The verb phrase "هليا ويندا هون=halya wenda hon=go" in the sentence (07) has only one argument to discuss about. Its

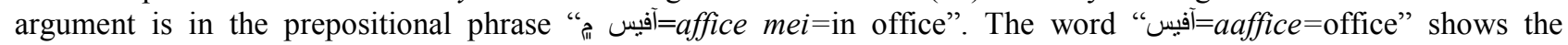
destination point of the action of the subject. It shows that the action of "going/getting back" ends at the common noun "office". We can thus say that this argument is goal having goal theta role in the sentence. It also shows the place or location of the subject in the sentence.

The verb phrase "اجي ويندا آهيون=achi wenda aahyon=come/ come back/ arrive" in the sentence (08) has only one

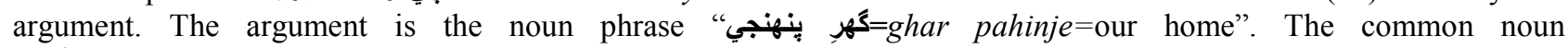

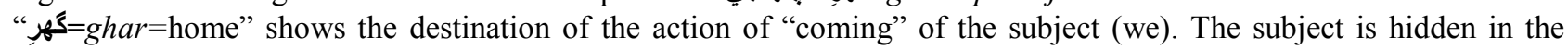
surface structure of the sentence; however, deep structure of the sentence shows that it has a subject which first person plural pronoun "we", which can be identified through verbal inflections. The subject (we) comes from somewhere (may be office) to the home. Thus, it can be said that the common noun " the sentence. It also shows the location or place of the subject in the sentence.

\subsubsection{Recipient Theta Role}

Carnie (2006) defines recipient as a special kind of goal that involves a change of possession in the sentence.

ايميل كئي شُن مونكي . Example 09

\begin{tabular}{|c|c|c|}
\hline $\begin{array}{l}\text { S. NO/ } \\
\text { coding }\end{array}$ & $\begin{array}{l}\text { Sentence } \\
\text { Description }\end{array}$ & Sentence \\
\hline \multirow[t]{5}{*}{ N525 } & Sindhi in Arabic & ايميل كئي ثن مونكي. \\
\hline & Sindhi in Roman & Email kai thun monkhy. \\
\hline & Transliteration & Email; kai=did; thun=they/them; monkhy=I. \\
\hline & Translation & They sent me an email. \\
\hline & $\begin{array}{l}\text { Syntactic } \\
\text { Analysis }\end{array}$ & $\begin{array}{l}\text { (Subject: (they) hidden subject, Object: ايميل=email=email, } \\
\text { Object complement: مونكي=monkhy=me, Verb Phrase: } \\
\text { ثكئ kai than=did/sent) }\end{array}$ \\
\hline
\end{tabular}




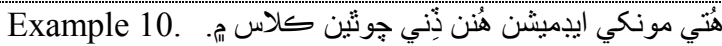

\begin{tabular}{|c|c|c|}
\hline $\begin{array}{l}\text { S. NO/ } \\
\text { coding }\end{array}$ & $\begin{array}{l}\text { Sentence } \\
\text { Description }\end{array}$ & Sentence \\
\hline \multirow[t]{5}{*}{ M331 } & Sindhi in Arabic & 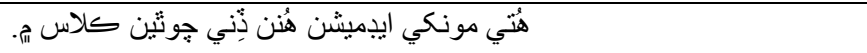 \\
\hline & Sindhi in Roman & Huty mokhy admission hunan dini chothei class mei. \\
\hline & Transliteration & $\begin{array}{l}\text { Huty=there; mokhy=I/me; admission; hunan=they/them; } \\
\text { dini=gave; chothei=fourth; class; mei=in. }\end{array}$ \\
\hline & Translation & They gave me admission there in fourth class. \\
\hline & $\begin{array}{l}\text { Syntactic } \\
\text { Analysis }\end{array}$ & 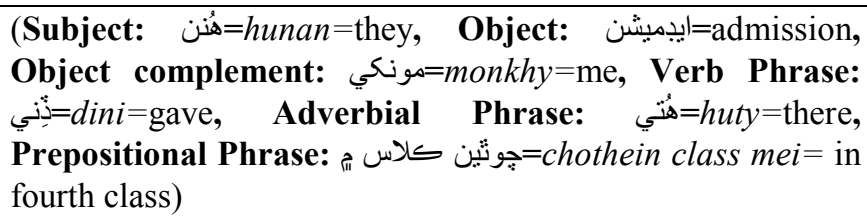 \\
\hline
\end{tabular}

The verb phrase "كئي ثن =kai than=did" in the sentence (09) takes two arguments to discuss about. The first argument "ايميل=email" is a common noun which can be any email. It is a direct object with an accusative case in the sentence. Hence; we can say that the argument "يميل=email" is the internal argument or direct object or the theme of the sentence. The second argument "مونكي=monkhy=me" is indirect object having a dative case, because it shows possession of something (an email). It does not do action in the sentence too, but it is the one which receives the argument "يميل=email" in the sentence. Therefore; it can be said that the argument "مونكي=monkhy=me" is the receiver of "يميل=email", and it has recipient theta role in the sentence.

The verb phrase "نذِن=dini=gave" in the sentence (10) takes three arguments with itself. The arguments are:

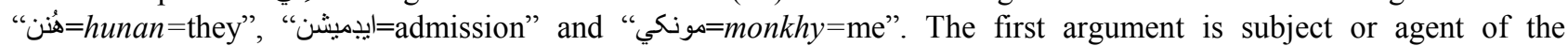
sentence and it has an agent theta role. The second argument "يديميشن=admission" is the internal argument or the direct object having an accusative case or the theme of the sentence, because it is with verbal group, and it has the theme theta role. The third argument is "مونكي=monkhy=me", it is an indirect object having dative case. However, it neither does an action nor undergoes an action of the sentence, but this is the argument which receives an admission in the sentence. It can be therefore said that the argument "مونكي=monkhy=me" is the recipient of the sentence and it has recipient thematic relation.

\subsubsection{Source Theta Role}

Source theta role as the opposite of goal; the entity from which movement occurs or something happens in a sentence, is called a source theta role (Carnie, 2006).

\begin{tabular}{|c|c|c|}
\hline $\begin{array}{l}\text { S. } \mathrm{NO} / \\
\text { coding }\end{array}$ & $\begin{array}{l}\text { Sentence } \\
\text { Description }\end{array}$ & Sentence \\
\hline \multirow[t]{5}{*}{ N765 } & Sindhi in Arabic & 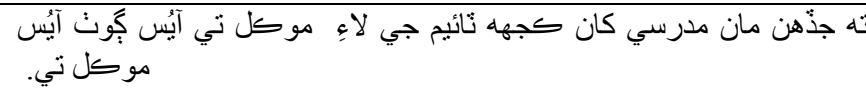 \\
\hline & Sindhi in Roman & $\begin{array}{l}\text { Ta jadahin maan maderse khan kujh time je lai mokal ty } \\
\text { ahyus ghoth aayus mokal ty. }\end{array}$ \\
\hline & Transliteration & $\begin{array}{l}\text { Ta=that; jadahin=when; maan=I; maderse=school; } \\
\text { khan=from; kujh=some; time; je= of; lai=for; mokal=leave; } \\
\text { ty=on; ahyus=came; ghoth=village; } \\
\text { mokal=leave; ty= on. }\end{array}$ \\
\hline & Translation & $\begin{array}{l}\text { That when I came to village from the madersah for some } \\
\text { time on vacation. }\end{array}$ \\
\hline & $\begin{array}{l}\text { Syntactic } \\
\text { Analysis }\end{array}$ & 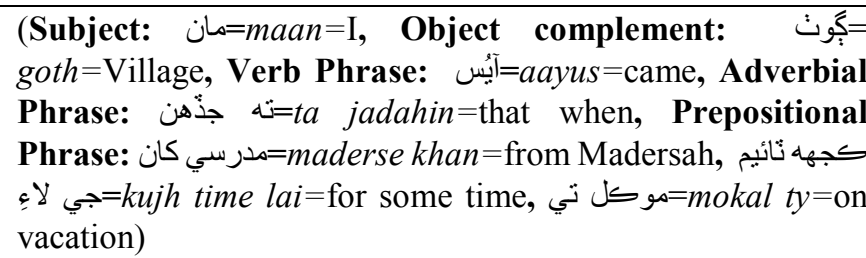 \\
\hline
\end{tabular}




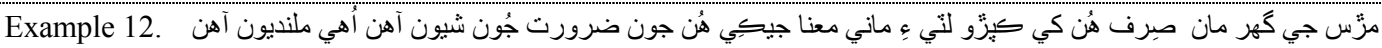

\begin{tabular}{|c|c|c|}
\hline $\begin{array}{l}\text { S. NO/ } \\
\text { coding }\end{array}$ & $\begin{array}{l}\text { Sentence } \\
\text { Description }\end{array}$ & Sentence \\
\hline \multirow[t]{5}{*}{ N656 } & Sindhi in Arabic & 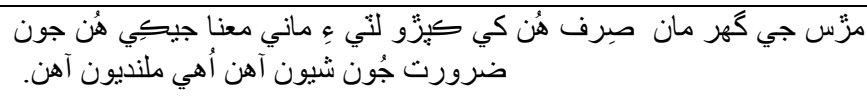 \\
\hline & Sindhi in Roman & $\begin{array}{l}\text { Murs je ghar maan srif hun khy kapro lati ain maani mana } \\
\text { jeke hun jon zaroorat jon shayon hin uhy milandion hin. }\end{array}$ \\
\hline & Transliteration & $\begin{array}{l}\text { Murs=husband; je=of; ghar=house; maan=from; srif=only; } \\
\text { hun=her; khy=have; kapro=cloth; lati=cloth; ain=and; } \\
\text { maani=bread; mana=means; jeke=that; hun=her; jon=of; } \\
\text { zaroorat=need; jon=of; shayon=things; hin=are; uhy=those; } \\
\text { milandion=will meet; hin=are. }\end{array}$ \\
\hline & Translation & $\begin{array}{l}\text { She gets only clothing and food from her husband's house } \\
\text { means she gets only those (things) of her needs. }\end{array}$ \\
\hline & $\begin{array}{l}\text { Syntactic } \\
\text { Analysis }\end{array}$ & 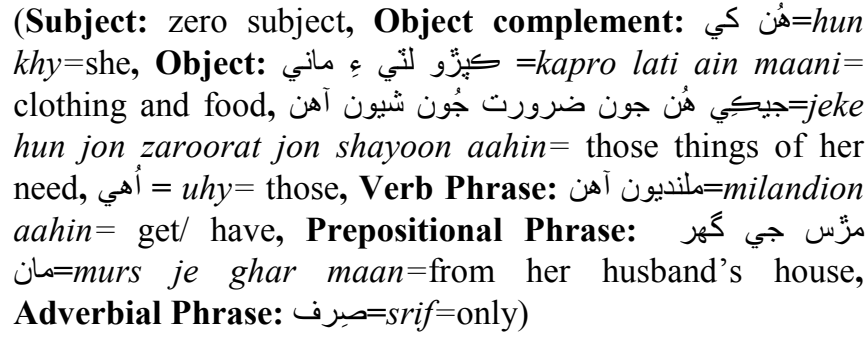 \\
\hline
\end{tabular}

The verb phrase "آيُّ=aayus=came" of the sentence (11) has two noun phrases and three prepositional phrases. The

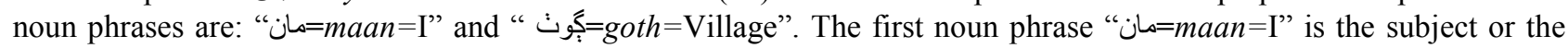
agent having a nominative case in the sentence, and it has an agent theta role in the sentence. The second argument "نو=goth=Village" is the goal of the sentence, and it has the goal theta role in the sentence. This argument also shows the place or location of the subject (the village where subject is coming to). The common noun

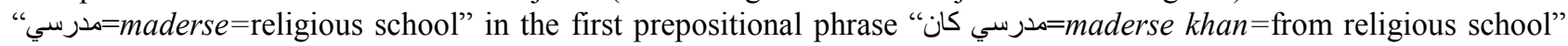
shows the "source" of action of the sentence, thus it has an ablative case in the sentence, because it shows source in the sentence. Therefore; we can say that this common noun is source of the action, and it has source theta role in the sentence.

The verb phrase "ملنديون آهن=milandion aahin=get" in the sentence (12) has four arguments and a complement phrase to discuss about. The first noun phrase "هن هن كي This is the argument which takes benefit in the sentence; thus, we can say that this argument is beneficiary of the sentence. The second argument "كيرّ" لني عِ ماني=kapro lati ain maani=clothing and food" is the theme of the sentence, and it has the theme thematic relation in the sentence. The noun phrase " مرّّس جي كهر " murs je ghar=husband's house" prepositional phrase shows source of the things that she gets. Therefore; it can be said that the noun phrase " مرّس جي كهر " =murs je ghar=husband's house" is the source of getting food and clothing in the sentence, and it has the source theta role.

\subsubsection{Locative Theta Role}

Carnie (2006) defines locative to be the place where action occurs.

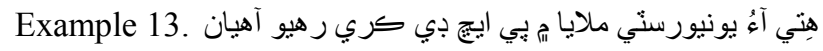

\begin{tabular}{|c|c|c|}
\hline $\begin{array}{l}\text { S. NO/ } \\
\text { coding }\end{array}$ & $\begin{array}{l}\text { Sentence } \\
\text { Description }\end{array}$ & Sentence \\
\hline \multirow[t]{5}{*}{ M16 } & Sindhi in Arabic & 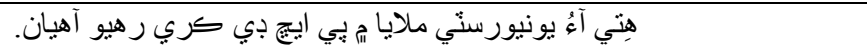 \\
\hline & Sindhi in Roman & Hity aaon University Malaya mei PhD kary rahyo aahiyan. \\
\hline & Transliteration & $\begin{array}{l}\text { Hity=here; aaon=I; University; Malaya; mei=in; PhD; } \\
\text { kary=do; rahyo=agreement (ing form); aahiyan=am. }\end{array}$ \\
\hline & Translation & I am doing $\mathrm{PhD}$ here in University Malay. \\
\hline & $\begin{array}{l}\text { Syntactic } \\
\text { Analysis }\end{array}$ & 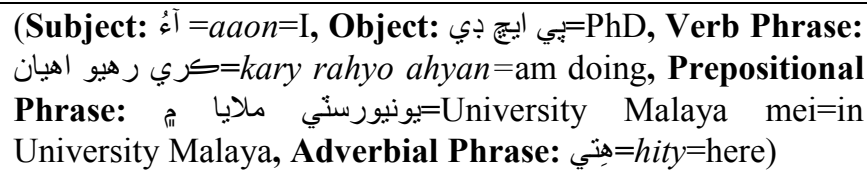 \\
\hline
\end{tabular}




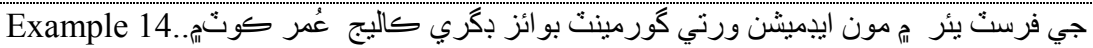

\begin{tabular}{|c|c|c|}
\hline $\begin{array}{l}\text { S. NO/ } \\
\text { coding }\end{array}$ & $\begin{array}{l}\text { Sentence } \\
\text { Description }\end{array}$ & Sentence \\
\hline \multirow{5}{*}{ M460 } & Sindhi in Arabic & 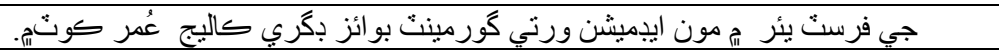 \\
\hline & Sindhi in Roman & $\begin{array}{l}\mathrm{Ji} \text {, first year mei moon admission warti Government Boys Degree } \\
\text { College Umar Kot mei. }\end{array}$ \\
\hline & Transliteration & $\begin{array}{l}\mathrm{Ji}=\text { yes; first; year; mei=in; moon=I; admission; } \\
\text { government; boys; degree; college; Umar Kot; mei= in. }\end{array}$ \\
\hline & Translation & $\begin{array}{l}\text { Yes, I got admission in first year in Government Boys Degree College } \\
\text { Umar Kot. }\end{array}$ \\
\hline & $\begin{array}{l}\text { Syntactic } \\
\text { Analysis }\end{array}$ & 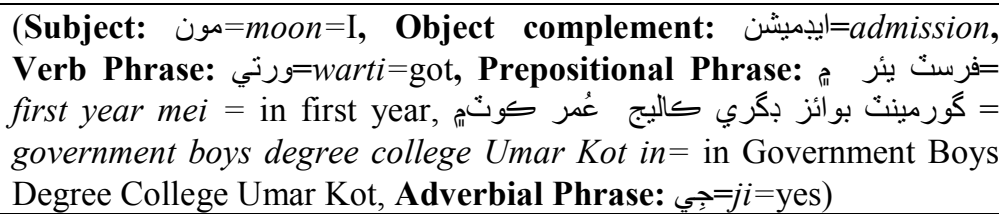 \\
\hline
\end{tabular}

The verb phrase in the sentence (13) has two noun phrases, a prepositional and an adverbial phrase. The first argument

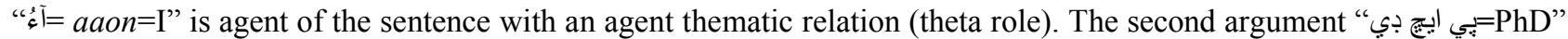
is a proper noun, a name of a higher degree. It is object or theme of the sentence, and it has theme theta role in the sentence. The prepositional phrase "يونيورسني ملايا "University Malaya mei=in University Malaya" shows the place

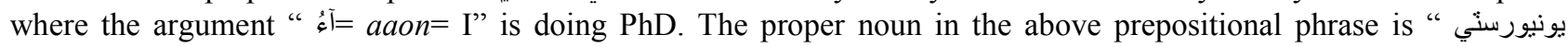
ملايا =University Malaya". It is also a name of the institution, the place as well as the location. Therefore; it can be said that it is locative of the sentence and it has locative theta role.

The verb phrase in the sentence (14) is "ونون=warti=got". It has two noun phrases, two prepositional phrases. The first argument "مون=moon=I" is the subject having nominative case (because it performs action in the sentence) or the agent of the sentence. The second argument is "يديميشن=admission" the theme of the sentence and it has theme theta role in the sentence. The proper noun "كورمينت بو ائز بكري كاليج عُمر كوث" =government boys degree college Umar Kot=Government Boys Degree College Umar Kot" shows the place or location of the action (where admission was got). Therefore; it can be said that this argument is locative of the sentence, and it has locative thematic relation.

\subsubsection{Instrument Theta Role}

Carnie (2006) gives a brief definition of instrument as the entity with which action occurs or with which subject does an action in the sentence.

أن جو اسان كي جو اب ذيو ايميل جي ذريعي. Example

\begin{tabular}{|c|c|c|}
\hline $\begin{array}{l}\text { S. NO/ } \\
\text { coding }\end{array}$ & $\begin{array}{l}\text { Sentence } \\
\text { Description }\end{array}$ & Sentence \\
\hline \multirow[t]{5}{*}{ N530 } & Sindhi in Arabic & أن جو اسان كي جواب ذّيو ايميل جي ذريعي. \\
\hline & Sindhi in Roman & Una jo assan khy jawab dio email je zarie. \\
\hline & Transliteration & $\begin{array}{l}\text { Una=that; jo=of; assan=we; khy=have; jawab=answer; dio=give; } \\
\text { email; je }=\text { of; zarie= through. }\end{array}$ \\
\hline & Translation & Give us its reply through an email. \\
\hline & $\begin{array}{l}\text { Syntactic } \\
\text { Analysis }\end{array}$ & 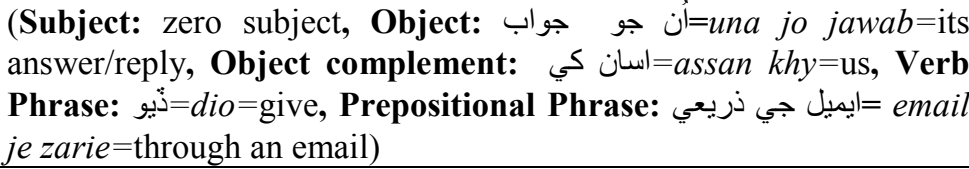 \\
\hline
\end{tabular}

بxample 16.بائيك تي ويندا ها سين بابا سان كَّ سِّو اسكول

\begin{tabular}{|c|c|c|}
\hline $\begin{array}{l}\text { S. NO/ } \\
\text { coding }\end{array}$ & $\begin{array}{l}\text { Sentence } \\
\text { Description }\end{array}$ & Sentence \\
\hline \multirow[t]{5}{*}{ M371 } & Sindhi in Arabic & بائيك تي ويندا ها سين بابا سان كذّ سيدو اسكول. \\
\hline & Sindhi in Roman & Bike ty wenda haa sein baba saan gad sidho iskool. \\
\hline & Transliteration & $\begin{array}{l}\begin{array}{l}\text { Bike; ty=on; } \\
\text { baba=father; } \\
\text { iskool=school. }\end{array} \text { saan=will } \begin{array}{r}\text { go; } \quad \text { haa=were; } \\
\text { gad=together; }\end{array} \quad \begin{array}{r}\text { sein=agreement; } \\
\text { sidho=direct; }\end{array}\end{array}$ \\
\hline & Translation & (We) used to go direct to the school on the bike with father. \\
\hline & $\begin{array}{l}\text { Syntactic } \\
\text { Analysis }\end{array}$ & 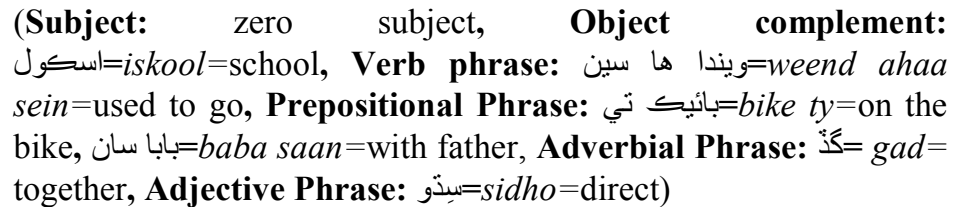 \\
\hline
\end{tabular}


The verb phrase "ذيو=dio=give" of the sentence (15) has four arguments (two noun phrases and one prepositional phrase) to talk about. The first argument "أن جو جواب=una jo jawab=its answer/reply" is the direct object or the theme of the sentence, and it has the theme theta role. The second argument "سssan khy=us" is the goal of the sentence, because it tells the destination of answer to go (from the second person to first). The common noun "ايميل=email" does not any action in the sentence except to be used as an instrument to do an action of "giving" the answer/reply to the argument "اسان كي=assan khy=us". Therefore; we can say that the common noun "ايميل=email" is used as an instrument to do action of replying, and it has the instrument theta role.

The verb phrase "ويندا ها سين=weend ahaa sein=used to go" in the sentence (16) has one noun phrase and two prepositional phrases. The first noun phrase or the argument "lسكول"iskool=school" is the goal of the sentence, and it has the GOAL theta role. The common noun "بائيك=bike=bike" in the prepositional phrase "نيائيك "bike ty=on the bike" shows that it is an instrument of the sentence. It neither does an action nor undergoes an action of the sentence. It is used just as a means to go to school. We can therefore say that it is instrument having instrument theta role in the sentence.

\subsubsection{Beneficiary}

The entity for whom the action occurs in the sentence. (Carnie, 2006)

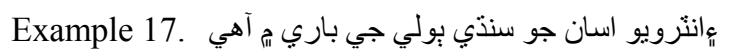

\begin{tabular}{|c|c|c|}
\hline $\begin{array}{l}\text { S. NO/ } \\
\text { coding }\end{array}$ & $\begin{array}{l}\text { Sentence } \\
\text { Description }\end{array}$ & Sentence \\
\hline \multirow[t]{5}{*}{ N9 } & Sindhi in Arabic & 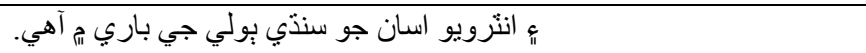 \\
\hline & Sindhi in Roman & Ain interview assan jo Sindhi boli je bary mei aahy. \\
\hline & Transliteration & $\begin{array}{l}\text { Ain=and; interview; } \quad \text { assan=we; } \quad \text { jo=of; } \\
\text { boli=language; } j \mathrm{e}=\text { of; bary=about; mei=in; ahy=is. }\end{array}$ \\
\hline & Translation & And our interview is about Sindhi Langauge. \\
\hline & $\begin{array}{l}\text { Syntactic } \\
\text { Analysis }\end{array}$ & 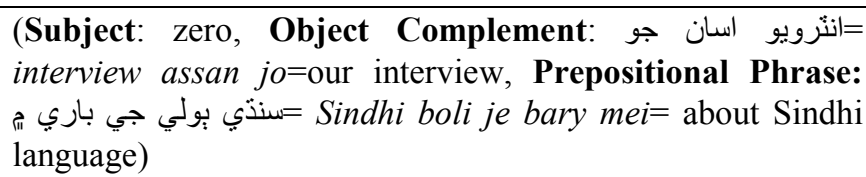 \\
\hline
\end{tabular}

Example 18. تهه اتي لهوُ مونكي كذّ وني ويو

\begin{tabular}{|c|c|c|}
\hline $\begin{array}{l}\text { S. NO/ } \\
\text { coding }\end{array}$ & $\begin{array}{l}\text { Sentence } \\
\text { Description }\end{array}$ & Sentence \\
\hline \multirow[t]{5}{*}{$\mathbf{N 3 8 3}$} & Sindhi in Arabic & تهه اتي هُوْ مونكي كذّوني ويو. \\
\hline & Sindhi in Roman & Ta uty hoo monkhy gad wathee wayo. \\
\hline & Transliteration & $\begin{array}{l}\text { Ta=that; uty=there; hoo=he; monkhy=I/me; gad=together; } \\
\text { wathee=take; wayo=went. }\end{array}$ \\
\hline & Translation & That he took me there together with himself. \\
\hline & $\begin{array}{l}\text { Syntactic } \\
\text { Analysis }\end{array}$ & 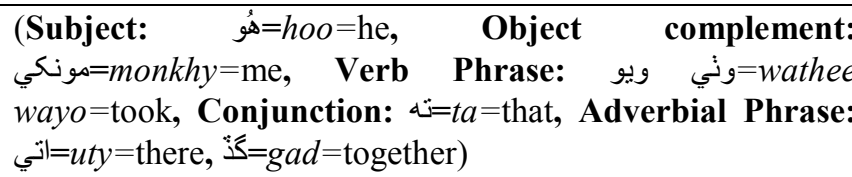 \\
\hline
\end{tabular}

The verb phrase of the sentence (17) is "هي "هي =ahy=have/has", and it has two arguments to discuss about. The first argument is a noun phrase: "نتنرويو اسان جو= interview assan jo=our interview". It is used at the place of subject, but it is not subject of the sentence, because it does not perform any function; in fact it is something which is talked about in the sentence. Thus, we can say it is theme of the sentence with theme thematic relation. The second argument is the proper noun "سنذي بولي Sindhi boli=Sindhi language". It is neither subject which does an action nor object which undergoes an action of the sentence, but it is the noun phrase (argument) which takes benefit from the sentence. This argument takes benefit of being interviewed; meaning that someone interviews someone about the Sindhi language; Sindhi language takes benefit without doing anything in the sentence. We can therefore say that it is beneficiary of the sentence (17), and it has a beneficiary theta role.

The verb phrase "وني ونيو=wathee wayo=took" in the sentence (18) has two arguments to discuss about. Its arguments

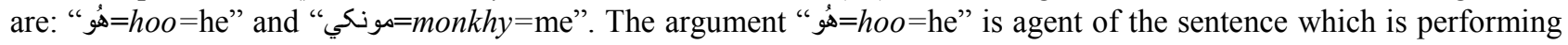
an action of taking someone to somewhere in the sentence, and it has an agent theta role. The second argument "مونكي =monkhy=me" is an indirect object of the sentence which is used at the place of object. This argument neither performs an action nor undergoes an action of the subject. However, this is the argument which takes benefit from the 
action of the agent of the sentence. We can therefore say that this argument is the beneficiary of the sentence and it has beneficiary theta role.

\subsection{Prominent Theta-roles in the Sindhi language}

There is no fixed or permanent hierarchy of the theta roles (Dowty, 1991). Linguists are just trying their best to study theta roles according to their languages and their perspectives. However, they agree that Agent theta role is structurally and thematically higher (prominent and frequent in use) than other theta roles. In this chapter, it is therefore analysed to see the most prominent theta roles used in the Sindhi language. Our data show that there are six prominent theta roles in Sindhi language, which are discussed below.

\subsubsection{Agent Theta Role}

تxample 19. ته أن جي كري معنا مان هِتي جوب كندو آهيان

\begin{tabular}{|c|c|c|}
\hline $\begin{array}{l}\text { S. NO/ } \\
\text { coding }\end{array}$ & $\begin{array}{l}\text { Sentence } \\
\text { Description }\end{array}$ & Sentence \\
\hline \multirow[t]{5}{*}{ N176 } & Sindhi in Arabic & تها أن جي كري معنا مان هِتي جوب كندو آهيان. \\
\hline & Sindhi in Roman & Ta una je kary mana maan hity job kando ahyan. \\
\hline & Transliteration & $\begin{array}{l}\text { Ta }=\text { that; una }=\text { that; je }=\text { of; kary }=\text { do; mana }=\text { means; maan }=\mathrm{I} \text {; } \\
\text { hity=here; job; kando }=\text { will; ahyan }=\text { am. }\end{array}$ \\
\hline & Translation & That is why I do job here. \\
\hline & $\begin{array}{l}\text { Syntactic } \\
\text { Analysis }\end{array}$ & 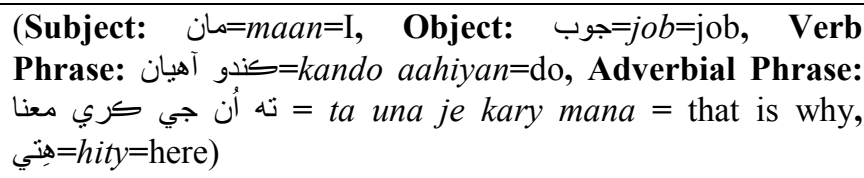 \\
\hline
\end{tabular}

The verb phrase of the sentence (19) is "كندو آهيان=kando aahiyan=do". The verb "هندو آهيان=kando aahiyan=do" is a transitive verb in the Sindhi language, and it requires a subject and object to give complete meaning of the sentence. It shows that who is doing what in the sentence. It is an action verb which requires an agent to do something in the sentence. It shows that someone does a job somewhere; meaning that an agent/a subject does a job that is why speaker uses this verb to show agent theta role prominently used in the sentence. The argument "مانmaan=I" is subject or an agent of the sentence that performs action of doing a job. The context of the sentence shows that there can be three reasons behind using Agent theta role prominently. Firstly, the verb phrase " "آهيان=kando aahiyan=do" is a transitive verb which needs minimum two arguments (subject and object) to give complete meaning of the sentence. Thus, in this way, verb phrase of the sentence (19) makes speaker use subject/agent prominently to show action in the sentence. Secondly, this verb is an action verb which requires an agent to do action that is why speaker uses Agent prominently. Thirdly, it is the context of the sentence which makes speaker use Agent prominently to show action of the sentence. Thus, it can be said that it is context of the sentence which pushes the speaker to use agent theta role prominently in the sentence.

3.2.2 Theme Theta Role

Example 20. اسان كي بابا اسكول مو كليندو هو

\begin{tabular}{|c|c|c|}
\hline $\begin{array}{l}\text { S. NO/ } \\
\text { coding }\end{array}$ & $\begin{array}{l}\text { Sentence } \\
\text { Description }\end{array}$ & Sentence \\
\hline \multirow{5}{*}{231} & Sindhi in Arabic & اسان كي بابا اسكول مو كليندو هو. \\
\hline & Sindhi in Roman & Assan khy baba iskool mokleendo ho. \\
\hline & Transliteration & $\begin{array}{l}\text { Assan=we; khy=have; baba=father; } \quad \text { iskool=school; } \\
\text { mokleendo=will send; ho=was. }\end{array}$ \\
\hline & Translation & $\begin{array}{l}\text { Father would send us to school. Or } \\
\text { Father used to send us to school. }\end{array}$ \\
\hline & $\begin{array}{l}\text { Syntactic } \\
\text { Analysis }\end{array}$ & 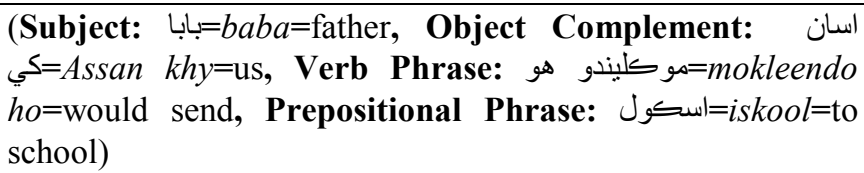 \\
\hline
\end{tabular}

The verb phrase of the sentence (20) is "مو كليندو هو=mokleendo ho=would send/used to send". The morpheme " " sentence. It is an action verb which needs an agent to do action in the sentence. The speaker is compelled (because of the context) to use Agent and Theme theta roles prominently in order to show the action of sending something from someone to someone else. However, in this sentence, the speaker focuses on the Theme in order to show the thing that undergoes the action of the sentence. The context of the verb phrase (being transitive verb and an action verb) makes 
the speaker use subject/agent and object/theme prominently. The speaker is trying to show that his father would not send them; where 'father' is the agent/subject of the sentence and 'us' is theme of the sentence. Therefore; it can be said that it is context of the sentence which makes the speaker to use a verb which uses prominently the theme theta role in the sentence.

\subsubsection{Recipient Theta Role}

تقريين صُبح تائين مونكي أنهن جو ميسيج اجِي ويو موبائيل تي Example 21

\begin{tabular}{|c|c|c|}
\hline $\begin{array}{l}\text { S. } \mathrm{NO} / \\
\text { coding }\end{array}$ & $\begin{array}{l}\text { Sentence } \\
\text { Description }\end{array}$ & Sentence \\
\hline \multirow[t]{5}{*}{ N495 } & Sindhi in Arabic & تقريين صُبح تائين مونكي أنهن جو ميسيج اجِي ويو موبائيل تي. \\
\hline & Sindhi in Roman & $\begin{array}{l}\text { Taqreeban subho taien monkhy unhan jo message achi wayo } \\
\text { mobile ty. }\end{array}$ \\
\hline & Transliteration & $\begin{array}{l}\text { Taqreeban=amost; } \quad \text { subho=morning; } \\
\text { monkhy=I/me; unhan=them; jo=of; message; achi=come; } \\
\text { wayo=went; mobile; ty=on. }\end{array}$ \\
\hline & Translation & $\begin{array}{l}\text { I got their message on my mobile by in the morning. Or } \\
\text { I received their message on mobile very soon. }\end{array}$ \\
\hline & $\begin{array}{l}\text { Syntactic } \\
\text { Analysis }\end{array}$ & 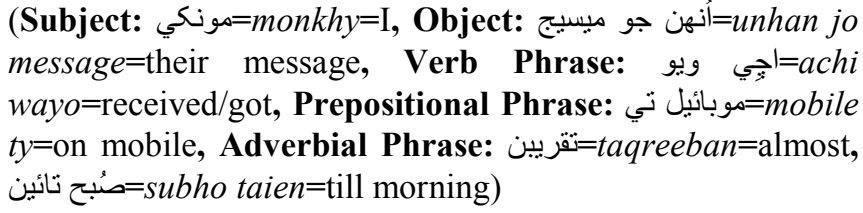 \\
\hline
\end{tabular}

The verb phrase of the sentence (21) is "اجي ويو=achi wayo=received/got". This verb phrase has been used as a transitive verb which requires minimum two arguments (subject and object) to show complete action of the sentence. The verb shows action of coming something to someone; it shows something (a message/ an sms) comes to someone from someone else that is why the verb needs a person (a recipient) who receives the message in the sentence, which makes speaker to use the recipient theta role prominently. The context of the sentence shows that the speaker tries to show that someone sent him a message on his mobile phone number. It shows that they (subject/agent) sent a message (object/theme) to him (recipient); where 'they' is an agent; 'a message' is a theme and 'him' is a recipient of the message. It is context of the situation which makes the speaker use such verb which shows recipient theta role prominently in the sentence.

\subsubsection{Locative Theta Role}

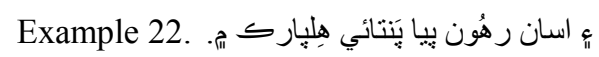

\begin{tabular}{|c|c|c|}
\hline $\begin{array}{l}\text { S. NO/ } \\
\text { coding }\end{array}$ & $\begin{array}{l}\text { Sentence } \\
\text { Description }\end{array}$ & Sentence \\
\hline \multirow{5}{*}{106} & Sindhi in Arabic & 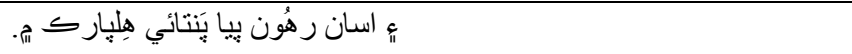 \\
\hline & Sindhi in Roman & Ain assan rahon paya pantai hillpark mei. \\
\hline & Transliteration & $\begin{array}{l}\text { Ain=and; assan=we; rahon=living; paya=are; pantai } \\
\text { hillpark; mei=in. }\end{array}$ \\
\hline & Translation & and we are living in Pantai Hill park. \\
\hline & $\begin{array}{l}\text { Syntactic } \\
\text { Analysis }\end{array}$ & 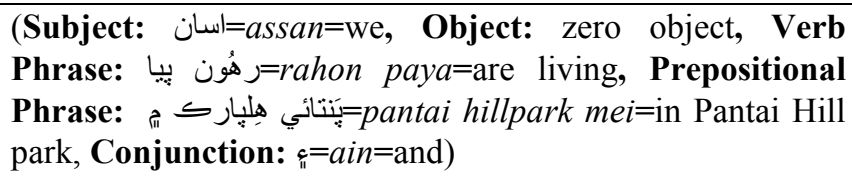 \\
\hline
\end{tabular}

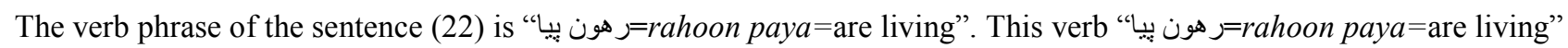
is an intransitive verb whose action does not pass from subject to the object rather it remains only to the subject of the sentence. It is an action verb which requires an agent to do action in the sentence. The verb shows action of living somewhere by someone; it shows someone (the speaker) is living somewhere called Pantai hillpark that is why speaker uses a verb that needs an argument (an area) to be shown as location of living in the sentence. It is the context of the sentence which makes the speaker to prominently use the locative theta role in order to show location of living in the sentence. Therefore; it can be said that it is context of the sentence which makes the speaker to use a verb which shows prominently the locative theta role in the sentence. 
3.2.5 Beneficiary Theta Role

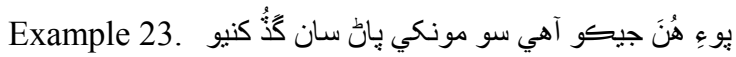

\begin{tabular}{|c|c|c|}
\hline $\begin{array}{l}\text { S. NO/ } \\
\text { coding }\end{array}$ & $\begin{array}{l}\text { Sentence } \\
\text { Description }\end{array}$ & Sentence \\
\hline \multirow[t]{5}{*}{ N381 } & Sindhi in Arabic & 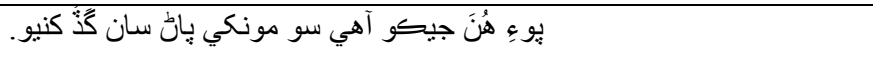 \\
\hline & Sindhi in Roman & Poi hun jeko aahy so monkhy pan saan gad kanyo. \\
\hline & Transliteration & $\begin{array}{l}\text { Poi=then; hun=him; jeko=that; } \text { aahy=is; } \quad \text { so=that; } \\
\text { monkhy=me; pan=himself; saan=with; gad=together; } \\
\text { kanyo=took. }\end{array}$ \\
\hline & Translation & Then he took me together with himself. \\
\hline & $\begin{array}{l}\text { Syntactic } \\
\text { Analysis }\end{array}$ & 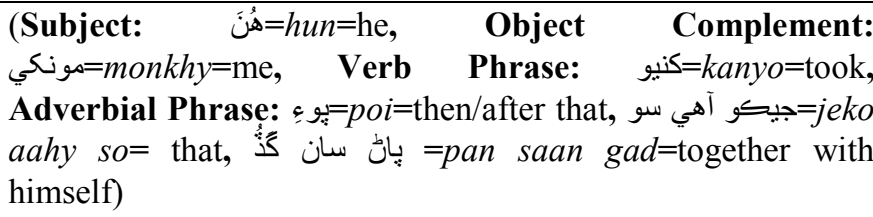 \\
\hline
\end{tabular}

The verb phrase of the sentence (23) is "كنيو=kanyo=took". It is a transitive verb (Rashidi, 2007) which needs two arguments subject and object to show complete action in the sentence. It is an action verb which requires an agent to do action in the sentence. The verb shows some action of an Agent; it shows someone is taking someone else to some place that is why the verb needs two persons (an Agent and a beneficiary) to show action of the sentence, which makes speaker to use Beneficiary theta roles prominently. It is context of the situation which makes the speaker use such verb which shows beneficiary theta role prominently in the sentence. The context of the sentence shows that the argument having beneficiary theta role (me) has been used prominently in order to show the beneficiary of the sentence.

\subsubsection{Goal Theta Role}

Example 24. أن وقت اسان جيكو آهي سو گهونّكي هليا وياسين

\begin{tabular}{|c|c|c|}
\hline $\begin{array}{l}\text { S. NO/ } \\
\text { coding }\end{array}$ & $\begin{array}{l}\text { Sentence } \\
\text { Description }\end{array}$ & Sentence \\
\hline \multirow[t]{5}{*}{$\mathbf{N 2 9 8}$} & Sindhi in Arabic & أن وقت اسان جيكو آهي سو گهونّكي هليا وياسين. \\
\hline & Sindhi in Roman & Una waqt assan jeko aahy so Ghotki halya wayasein. \\
\hline & Transliteration & $\begin{array}{l}\text { Una=that; waqt=time; assan=we; jeko=that; aahy=is; } \\
\text { so=that Ghotki; halya=went; wayasein=went/gone. }\end{array}$ \\
\hline & Translation & We went to Ghotki at that time. \\
\hline & $\begin{array}{l}\text { Syntactic } \\
\text { Analysis }\end{array}$ & 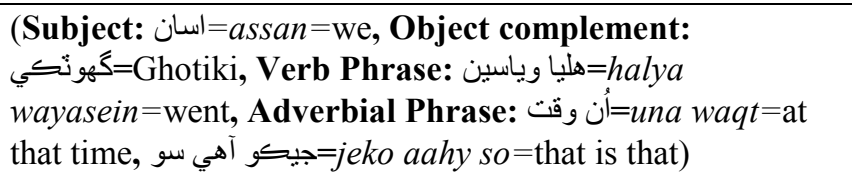 \\
\hline
\end{tabular}

The verb phrase of the sentence (24) is " هليا وياسين=halya wayasein=went". The verb shows action of going somewhere by someone; it shows someone (the speaker) is going somewhere called Ghotki which makes speaker to use a verb that needs an argument (a place: Ghotki) to be shown as destination or goal of action in the sentence. Thus, speaker does not have any option but to use an argument prominently which shows goal of action in the sentence. This verb is an intransitive verb in Sindhi language, and it does not require an object or a theme to be used at the object position in the sentence. However, such verb does need an argument which shows goal of action in the sentence. The speaker is trying to show that he along with his friend went to Ghotiki; where 'we/they' is the agent/subject of the sentence and 'Ghotiki' is goal of the sentence. Therefore; it can be said that it is context of the sentence which pushes the speaker to use a verb which uses prominently goal theta role in the sentence.

\section{Conclusion}

The number of theta roles differs from language to language; every language has certain number of theta roles and thematic relations assigned to their arguments in sentences. This study tried to analyse and investigate the prominent theta roles with the help of the theoretical framework proposed by Carnie (2006). It has been found from the data that the Sindhi language has all the theta roles which are proposed by Carnie (2006). The data (1,649 sentences) in this research study show that the Sindhi language has all (09) theta roles (what Carnie has proposed) and some strange cases. Carnie's nine proposed theta roles are: agent, experiencer, theme, goal, recipient, locative, source, instrument and beneficiary. Out of these nine, six theta roles have been found prominent in the Sindhi language. The six prominent theta roles assigned by the verbs to their arguments are: agent, theme, beneficiary, recipient, locative and goal. Sindhi language is one of the languages which are known as agreement language languages (Chomsky, 1995). The verbs of the 
Sindhi language are mostly action verbs which need an agent to do an action in sentences. An agent needs mostly a theme to undergo its action in a sentence. The Sindhi verbs have beneficiaries which benefit from the action of the agent and theme in a sentence. The Sindhi verbs also have recipient which re recipients of something in a sentence. According to the study of Hovav M. R. (2004), the hierarchy of the prominent theta roles in the Sindhi language is: Agent $>$ theme $>$ beneficiary $>$ recipient $>$ locative $>$ goal. However; this is not the final one; broader study is to be carried out to find exact hierarchy of the theta roles in Sindhi.

\subsection{Contribution}

The primary aim of this study is to apply the theta role theory on the Sindhi language verbs using the framework proposed by Carnie (2006). This study has successfully applied the theory on the verbs of Sindhi language. As we know from the literature, in Sindhi, thematic roles have not yet been analysed and investigated using the theory applied to the current study. Thus, this study serves as a preliminary in the area; it gives way for conducting similar research on the area in future. The same research can be replicated in the syntax of other languages in the world. This research work can be used as base to conduct research in syntax especially in theta roles and prominent theta roles in any languages.

\section{References}

Adwani, B. (1985). وذّو سنتي وياكرن: Jamshoro.: Institute of Sindhalogy, Jamshoro, Sindh.

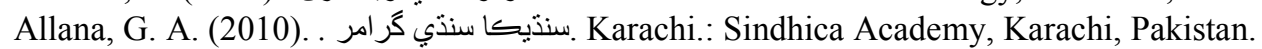

Arshad, A. (1986). فيق گر امر Hala.: International Academy, Hala, Sindh, Pakistan.al.,.

Baker, M. C. (1996). Thematic Roles and Syntactic Structure. Liliane Haegeman (ed). Iin Elements of Grammar, 73137.

Be, M. Q. (2006). سنتي وياكرث Hyderabad: Qaleech, M. (2006). سنتي وياكرث (J. Sindhi Adabi Board Ed.). Hyderabad.: Sindhi Adabi Board, Jamshoro, Sindh, Pakistan.

Bierwisch, M. (2006). Thematic Roles- Universal, Particular, and Ideosyncratic Aspects. Ina Bornknessel, Matthias Schlesewsky, Bernard Comrie, Angela D. Friederici (Eds. Semantic Role Universals and Argument Linking, Walter de Gruyter, Berlin, 89-126.

Carnie, A. (2006). A general Introduction (Second ed.). USA.: Blackwell Publishers Ltd.

Chano, M. I. (2011). آسان سنتي كر امر Mehrabpur, Sindh, Pakistan.: M. Sindhi Sahat Ghar, Sindh, Pakistan. Ed.

Devis, A. R. (2009). Thematic Roles. online 1 (202) 449-1315.

Dowty, D. (1991). Thematic Proto-Roles and Argument Selection. Language, 67(3), 547-619.

Ezeizabarrena, M. J. (2012). The (in)consistent ergative marking in early Basque: L 1 vs child L 2. Lingua(122), 303317.

Grimshaw, J. (1990). Argument Structure: Cambridge, Massachusetts: MIT Press.

Hackl, M. (2013). The Synax-semantics interface. Lingua(130), 66-87.

Harley, H. (2013). External Arguments and the Mirror Principle: On the distinctness of Voice and v. Lingua(125), 3457.

Holmberg, A. R., I. (2013). The syntax-morphology relation. Lingua(130), 111-131.

Jokhio, A. H. (2011). وياكرن جي اهم جُزفعل جو مختصر إيّاس. . Sindhi Boli Tahqeeqi Journal, Sindhi Language Authority, Hyderabad, Sindh, Pakistan. , 2, 78-100., 78-100.

Jokhio, A. H. (2012). جزم جي ذُرست استعمال جو مسعلو. Sindhi Boli Tahqeeqi Journal, Sindhi Language Authority, Hyderabad, Sindh, Pakistan, 68-90.

Jokhio, A. H. (2013a). فحل لازمي ". فعل متعدي جو مختصر إياس. Sindhi Boli Tahqeeqi Journal, Sindhi Language Authority, Hyderabad, Sindh, Pakistan., 4175ذ.

Jokhio, A. H. (2013b). وضاحت در وضاحت. Sindhi Boli Tahqeeqi Journal, Sindhi Language Authority, Hyderabad, Sindh, Pakistan., 160-162.

Lehman, C. (2005). Participant roles, thematic roles and syntactic relations. Paper presented at the SKY Conference on 'Syntactic Functions-Focus on the Periphery', Helsinki, 14-15. 11. 2003.

Luuk, E. (2009). The Noun/Verb and Predicate/Argument Structure. Lingua, 119, 1707-1727.

Marantz, A. (2013). Verbal argument structure: Evidents and participants. Lingua(130), 152-168.

Radford, A. (2009). Introduction to English Sentence Structure.: Cambridge: Cambridge University Press.

Rappaport, M. H. L., B. (2004). Deconstructing Thematic Hierarchies. Architectures, Rules, and Prferences: Afrestschrift for Joan Bresnan (pp. 451-468): Stanford, CA: CSIL Publications.

Rashidi, M. (2007). سوجهرو Kandyaro: Roshini Publication Kandyaro, Sindh, Pakistan.

Sindhi, D. (2010). سنذيكا سنذي كر امر. Karachi: Sindhica Academy, Karachi, Sindh, Pakisan.

Swart, P. d. e. a. (2008). Animacy. argument structure, and argument encoding. Lingua(118), 131-140.

Verhoeven, E. (2014). Thematic Prominence and animacy asymmeteries. Evidence from a cross-linguistic production study. Lingua, 143, 129-161.

Wechsler, S. (2005). Thematic Structure The Encyclopedic of language and Linguistics (Second ed.): Elsevier.

Williams, E. (1987). NP Trace in Theat Theory. Linguistics and Philosophy. Topics in Syntax and Semantics: NP, NonA Binding, 10(4), 433-447.

Willits, J. A. e. a. (2007). Distributional Statistics and Thematic Role Relationship. Paper presented at the Proceedings of the 29th Annual Meeting of the Cognitive Science Society. 